\title{
A Prospective Study of Zinc Level In Pregnant Women of Barpeta District of Assam and Pregnancy Outcome
}

\author{
${ }^{1}$ Dr. Kakoli Das. ${ }^{2}$ Dr. Dipti Bania. \\ ${ }^{2}$ Associate Professors, Department of Physiology, Fakhruddin Ali Ahmed Medical College and Hospital, \\ Barpeta, Assam, India.
}

\begin{abstract}
Introduction and Objectives : Women in this part of the country are mostly from the low socio-economic group and the diet they intake with low zinc and high fibre and phytate content may result in decreased bioavailability of zinc when there is increased demand during pregnancy. It is established that the requirement for zinc increases during period of rapid growth such as pregnancy, infancy and puberty. The main aim of the study was to find out the relationship between maternal and umbilical cord blood level of zinc as well as that of non-pregnant mothers in relation to pregnancy outcome especially the maturity of the baby.

Materials and Methods : The current study was a cross sectional study, conducted in the Barpeta district of Assam amongst 200 people who reported at Fakhruddin Ali Ahmed Medical College and Hospital. Sampled and labelled blood was estimated for the status of zinc by Flame Atomic Absorption Spectrophotometry. The results obtained was calculated in parts per million and statistically as range, mean, standard deviation and percentages.

Result: Of the total study population of 200 subjects, it was seen that the maternal serum zinc level was lower than the mean cord blood zinc level which was found to be highly significant $(p<0.001)$. The mean serum zinc levels of mothers giving birth to male babies was found to be slightly higher but not significant $(p>0.10)$. The percentage of term and pre-term babies were $87 \%$ and $13 \%$ respectively. Maternal and cord serum zinc level of pre-term babies were lower than that of term babies which is statistically found to be highly significant $(p<0.001)$.

Conclusion: Our study clearly indicates a positive link between maternal and cord serum zinc levels and the foetal level of zinc depends on the status of zinc of the mother. Pre-term babies and their mothers showed low zinc levels than in the term babies and in their mothers.
\end{abstract}

Keywords: Zinc, Singleton pregnancy, Uncomplicated pregnancy, Barpeta district, Assam

\section{Introduction}

Zinc was known to the physicians of ancient India and is evident from the fact that its use finds a place in Ayurvedic medicine. It is one of the trace metals essential growth and development. The importance of zinc for the growth of rats and mice was first described as early as in 1934 [1]. Its significance to human health, was identified decades later [2]. Adequate zinc contributes to growth, lessens premature births and other complications and improves neonatal survival. It is estimated that the newborn contains approximately 60mgm of zinc [3]. During growth and maturation it increases and in a $70 \mathrm{~kg}$ adult, total body zinc ranges from $1.5 \mathrm{mgm}$ in females to $2.5 \mathrm{gm}$ in males. It is an important metabolic substance for both the mother and the fetus. It plays an important role in the growth and development of many organs. It takes part in the synthesis of RNA and DNA and it is thus essential for the growth of the animal; hence it is likely to play an important role in maternal and fetal development.

Zinc deficiency occurs during the period of increased physiological demand like pregnancy and lactation [4]. If there is a need for increased zinc supply during pregnancy it is possible that it must be met by various metabolic adaptations by the embryo [5]. Retention of zinc during pregnancy is most relevant and is supported by various studies [6]. During early pregnancy physiological adaptation may occur as is the case of the dilution effect of the plasma volume [7]. That the level of the zinc decreases is evident from the recent studies as well [8]. The zinc concentration of $500 \mu \mathrm{g} / \mathrm{dl}$ in the serum of pregnant women at the time of delivery is considered acceptable [8]. There were $64.5 \%$ low birth weight infants in the hypozincemic group versus $42.6 \%$ in the normozincemic group [9]. As pregnancy advances towards term, the serum zinc level of the mother decreases [10]. In case, of non-pregnant women the serum zinc level is always found to be higher than pregnant women $[1,2,6]$. 


\section{Materials And Methods}

A total of hundred pregnant women in the age group of twenty to forty years are considered for the study. A total of twenty non-pregnant women of the same age group served as control. The patients were permanent residents of the district of Barpeta, Assam. Singleton, uncomplicated pregnant women were considered for study.

Babies were examined immediately after delivery. Gestational age of the new-borns was done by the complete physical and neurological assessment according to the Apgar scoring system. Babies were weighed immediately after birth on beam weighing scale. The weighing machine is checked periodically by known standard weight. Head circumference is measured by fibre glass non-stretchable tape. It is measured along the most prominent part of the occiput and the supra-orbital frontal area. Crown-heel length is measured nearest to $0.1 \mathrm{~cm}$ on an infantometer. Chest circumference is measured at the level of the nipple by fibre glass tape. $5 \mathrm{ml}$ of umbilical cord blood is collected half an hour before delivery under aseptic and antiseptic conditions. Sampled blood is allowed to clot at room temperature. For proper clot retraction and to prevent the growth of organisms the sample is kept in the refrigerator at $4^{\circ} \mathrm{C}$, over night. Exterme care was taken to prevent haemolysis. It is then subjected to centrifugation at $3000 \mathrm{rpm}$ for $15 \mathrm{mins}$.

The samples obtained are strictly labelled and the final estimations of zinc by flame atomic absorption spectrophotometry. Serum zinc levels were estimated in parts per million. The conversion formula is $-1 \mathrm{ppm}=1 \mathrm{mg} / \mathrm{L}=0.1 \mathrm{mg} \%=1 \mu \mathrm{g} / \mathrm{ml}=100 \mu \mathrm{g} / \mathrm{dl}$. Zinc is calculated in $\mu \mathrm{g} / \mathrm{dl}$. Data analysis was done statistically.

\section{Results}

Two hundred and twenty patients were taken into consideration and twenty non-pregnant women were also taken who served as the control group. The study is the first of its kind in this region and was done on the voluntary basis. The first group of Table-1 consists of 100 pregnant women whose serum zinc level at the time of delivery ranges from $22.6 \mu \mathrm{g} / \mathrm{dl}$ to $83.5 \mu \mathrm{g} / \mathrm{dl}$ with a mean value of $48.65 \mu \mathrm{g} / \mathrm{dl}$ and standard deviation (SD) of +14.98 . The second group of Table- 2 consists of 100 newborn babies whose cord serum zinc level at the time of delivery ranges from 38.3 $\mu \mathrm{g} / \mathrm{dl}$ to $123.6 \mu \mathrm{g} / \mathrm{dl}$ with a mean value of $72.35 \mu \mathrm{g} / \mathrm{dl}$ and SD of +20.37 .

The third group of Table- 3 consists of 20 non-pregnant women with serum zinc level of 56.7 $\mu \mathrm{g} / \mathrm{dl}$ to $120.3 \mu \mathrm{g} / \mathrm{dl}$ with a mean value of $84.32 \mu \mathrm{g} / \mathrm{dl}$ and $\mathrm{SD}$ of +17.91 . Mean serum zinc level of the mother is significantly lower than that of the baby and non-pregnant women. From Table-2 it is evident that out of 100 babies, 52 are males and 48 are females with almost equal male female ratio. Mean serum zinc level of the mothers of male babies is $49.13 \mu \mathrm{g} / \mathrm{dl}$ while that of female babies is $47.57 \mu \mathrm{g} / \mathrm{dl}$. It is evident from Table-3 that there is not much difference in mean serum zinc level in the cord blood between male and female babies.

Table-4 shows that $87 \%$ of the babies are term and $13 \%$ are at pre-term and no cases are observed in the post term period. Mean serum zinc level of the mothers of the term babies is 50.23 $\mu \mathrm{g} / \mathrm{dl}$ and that of the preterm babies is $36.02 \mu \mathrm{g} / \mathrm{dl}$ which is much lower than the former. Table-5 shows that the mean cord blood zinc level in term babies is much higher than that of the preterm babies. The levels in both the groups are higher than their respective mean maternal serum zinc level.

Table-1. Zinc level between mother, baby and non-pregnant women.

\begin{tabular}{|l|l|l|l|l|}
\hline Groups & Numbers & SERUM ZINC LEVEL $(\mu \mathrm{g} / \mathrm{dl})$ & \multicolumn{1}{l|}{} \\
\hline & & Range & Mean & S.D. \\
\hline Mother & 100 & $22.6-83.5$ & 48.65 & +14.98 \\
\hline Baby(cord) & 100 & $38.3-123.6$ & 72.35 & +20.37 \\
\hline Non-pregnant & 20 & $56.7-120.3$ & 84.32 & +17.91 \\
\hline
\end{tabular}

Table - 2. Mother's zinc level according to the sex of the baby.

\begin{tabular}{|l|l|l|l|l|l|}
\hline & & \multicolumn{4}{|l|}{ SERUM ZINC LEVEL $(\mu \mathrm{g} / \mathrm{d} \mathrm{d})$} \\
\hline Sex & Numbers & Percentage & Range & Mean & S.D. \\
\hline Male & 52 & 52 & $22.6-83.5$ & 49.13 & +14.69 \\
\hline Female & 48 & 48 & $25.8-77.6$ & 47.57 & +15.21 \\
\hline Total & 100 & & & & \\
\hline
\end{tabular}


A Prospective Study of Zinc Level In Pregnant Women of Barpeta District of Assam and ..

Table -3. Sex and cord serum zinc level.

\begin{tabular}{|l|l|l|l|l|l|}
\hline & & & \multicolumn{3}{|l|}{ SERUM ZINC LEVEL $(\mu \mathrm{g} / \mathrm{dl})$} \\
\hline Sex & Numbers & Percentage & Range & Mean & SD \\
\hline Male & 52 & 52 & $38.3-123.6$ & 72.14 & +18.5 \\
\hline Female & 48 & 48 & $40.0-122.0$ & 72.54 & +22.53 \\
\hline Total & 100 & & & & \\
\end{tabular}

Table - 4. Mother's serum zinc level according to the maturity of the baby.

\begin{tabular}{|l|l|l|l|l|l|}
\hline & & \multicolumn{4}{|l|}{ SERUM ZINC LEVEL $(\mu \mathrm{g} / \mathrm{dl})$} \\
\hline Maturity & Numbers & Percentage & Range & Mean & S.D. \\
\hline Term & 87 & 87 & $28.8-83.5$ & 50.23 & +14.51 \\
\hline Pre-term & 13 & 13 & $22.6-65.6$ & 36.02 & +11.73 \\
\hline
\end{tabular}

Table -5. Cord serum zinc level according to the maturity of the baby.

\begin{tabular}{|l|l|l|l|l|l|}
\hline & & \multicolumn{4}{|l|}{ SERUM ZINC LEVEL $(\mu \mathrm{g} / \mathrm{dl})$} \\
\hline Maturity & Numbers & Percentage & Range & Mean & S.D. \\
\hline Term & 87 & 87 & $40.0-123.6$ & 74.41 & +19.67 \\
\hline Pre-term & 13 & 13 & $38.3-111.0$ & 58.38 & +19.42 \\
\hline Total & 100 & & & & \\
\hline
\end{tabular}

\section{Discussion}

The present study is carried out in the district of Barpeta, Assam, India from February 2016 to February 2017. It was seen that the mean mater nal serum zinc level was lower than the mean cord blood zinc level which was found to be statistically highly significant $(\mathrm{p}<0.001)$. This observation has similarity with the studies conducted in other parts of the country [6,7]. Higher cord values in comparison to mother's zinc level was explained because of high proteosynthetic activity in fetus and the active transportation of zinc by placenta regardless of maternal zinc status [2]. Mean serum zinc levels of mothers giving birth to male babies was found to be slightly higher than that of female babies, but was not statistically significant $(\mathrm{p}>0.10)$. In the cord blood, both the male and the female babies showed almost equal zinc levels. Some studies found higher cord and serum zinc in males than in female babies [6]. Our study also reveals that the percentage of term and the pre-term babies were $87 \%$ and 13\% respectively. Maternal and cord serum zinc levels of pre-term babies were lower than that of the term babies which is found to be statistically highly significant $(\mathrm{p}<0.001)$. Although maternal level decreases during normal pregnancy, we found lower maternal level in connection with pre-term than with term deliveries. This finding suggests that zinc deficiency may play a role in the initiation of pre-term labour [8,9]. Our results of low maternal level of zinc of pre-term labour than term deliveries was in accordance with other studies conducted in other parts of India [5].

\section{Conclusion}

Our study bears a positive relation between maternal and cord serum zinc levels and fetal level zinc would largely depend upon the zinc status of the mother. Therefore, it can be concluded that zinc deficiency may be a cause of pre-term labour. High incidence of low birth weight babies found in the present study has lower level of zinc along with their mothers. But on the whole proper monitoring, dietary intake, supplementation of zinc is required so that the newborn brought to this world does not prove to be a burden to the society. This study might serve as a torch bearer so that further studies can be carried out in other districts of Assam to bring down the incidence of low birth weight.

\section{References}

[1]. Toads, W.R.; Elvenjem, C.A. and Hart, E.G.: Zinc in the role of nutrition; American J.Physiol. 107: 146-156, 1934.

[2]. Prasas, L.S.N. et.al, (1974): Role of zinc in nutrition; Ind, Paed, Vol2, 12, 799-802.

[3]. Swanson, C.A, King, J.C. (1987); Zinc: Am J clin. Nutr; 4; 763-771.

[4]. Bahl, L. et.al. (1994): Study of serum zinc in neonates and their mothers in Shimla hills (Himachal Pradesh), Ind. J. Paed; 61; 571-575.

[5]. Aggete, T.J. (1985): Trace elements and human pregnancy and lactation and nutrition of children .R.K.Chandra, Ravan Press; 8; 137-155.

[6]. Hambridge, K.M. et. al.,: Zinc nutritional status during pregnancy; a longitudinal study: Am. J Clin, Nutr. 37 : 429 - 442.

[7]. Turtle, S. et. al.,: Factors affecting plasma zinc and copper in pregnancy: Prac; Nutr Soc; 43.

[8]. Killhoma, et. al,: The role of calcium, copper, iron and zinc in pre-term delivery and pre-mature rupture of fetal membrane: Gynaecol, obst Invet, 17; 194-201.

[9]. http; // www. healthhelper. com /vitamins /minerals /zinc. htm.

[10]. Tsunenobu. Tamura, Robert. L. Goldenberg, Kelley Johnston, Mary DuBard: Maternal plasma zinc concentration and pregnancy outcome; the American journal of clinical nutrition, May 2017, 105(5). 